\title{
Aspects of serum and sputum antibody in chronic airways obstruction
}

\author{
C. W. C L A R K E \\ Department of Bacteriology, Cardiothoracic Institute, Fulham Road, London SW $36 \mathrm{HP}$
}

\begin{abstract}
Clarke, C. W. (1976). Thorax, 31, 702-707. Aspects of serum and sputum antibody in chronic airways obstruction. Immunoglobulin levels and precipitating antibody against a range of microbial antigens were measured in simultaneously collected serum and sputum samples from patients with chronic bronchitis (11), cystic fibrosis (9), bronchiectasis (9), and asthma (4). Sputum was prepared by dialysis and high-speed centrifugation methods.

Results showed that it was possible to detect precipitating antibody in the sputum, and the rate was increased when both methods were used. A discrepancy was noted between the detection rate in the sputum and serum. This, combined with the lack of correlation between sputum and serum immunoglobulins, lack of relationship between bronchial inflammation and sputum immunoglobulins, and the lack of IgM in the sputum suggested that the antibody and immunoglobulin were locally produced.

Sputum IgA (7S) in patients with chronic bronchitis was significantly lower $(P<0.05)$ than that found in patients with cystic fibrosis and bronchiectasis. Significant differences $(P<0.05)$ were also noted in serum IgG levels between patients with chronic bronchitis, bronchiectasis, and cystic fibrosis while serum IgM levels in patients with chronic bronchitis were significantly lower $(P<0.05)$ when compared to serum levels in patients with cystic fibrosis.

The presence of precipitating antibody in the sputum raises the possibility that type III reactions may be important in the pathogenesis of these conditions.
\end{abstract}

The mechanisms of pathogenicity of microbial organisms in the respiratory tract, as in other areas of the body, are poorly understood (Smith, 1972). Additionally, the extensive resident flora of the upper respiratory tract (Austrian, 1968) makes difficult the assessment of the significance of organisms isolated from the sputum. Studies of precipitating antibody in the serum of patients with chronic airways obstruction against certain bacterial antigens (May, 1975) have attempted to deal with this problem although the significance of these results (Tager and Speizer, 1975) is still not clear. Previous studies have shown that it is possible to detect immunoglobulins and antibody against microbial and other antigens in sputum (Biberfeld and Sterner, 1971; Medici and Buergi, 1971; Falk, Okinaka, and Siskind, 1972; Gump et al., 1973; Ryley and Brogan, 1973; Shore, Potter, and Stuart-Harris, 1973; Deuschl and Johansson, 1974; Wallwork et al., 1974; Warren and Tse, 1974; Brogan et al., 1975; Clarke, 1975).
Bacterial infection of the lower respiratory tract is known to be frequent in chronic bronchia disorders such as chronic bronchitis, bronchiecta $-x$ sis, and cystic fibrosis whereas the norma $B$ bronchial tree is known to be sterile (Brumfitt Willoughby, and Bromley, 1957; Lees and Mc-3 Naught, 1959). This suggests that there may be ano abnormality of respiratory defences in patient? with these conditions.

The aim of the present study was to determine the immunoglobulin content and antibody response of patients with chronic airways obstruct tion against microbial antigens as measured in simultaneously collected sputum and serum samples in order to determine if these measurements would provide insight into the mechanisms of bacterial pathogenicity in these conditions.

\section{METHOD}

Patients with confirmed diagnoses of chroniç्ठ bronchitis (11), cystic fibrosis (9), bronchiectasis 
(9), and asthma (4) were selected for study. Submission of sputum to the Bacteriology Department served as entry to the study. Patients with sufficient sputum available on the morning of the study were then selected. No account was taken of the patient's age, sex, severity of disease, smoking history or treatment. The sputum obtained from each patient represented approximately 18 hours overnight collection. Bloodstained sputum was not used. A minimum of $20 \mathrm{ml}$ was required for analysis. This proved to be a limiting factor in the case of asthmatic patients as very few of the patients available produced this volume of sputum. Sputum purulence was classified as proposed by May (1972a). Blood was collected at the same time as the sputum collection. Serum was stored with sodium azide at $4^{\circ} \mathrm{C}$ until tested.

PREPARATION OF SPUTUM FOR EXAMINATION For immunological analysis sputum was prepared in two ways:

1. Four millilitres of sputum were subjected to high-speed centrifugation in a Measuring and Scientific Equipment (MSE) Superspeed 65 centrifuge at 54500 revolutions per minute (rpm) $(120000 \mathrm{~g})$ at a temperature of $4-6^{\circ} \mathrm{C}$ for 30 minutes (Ryley and Brogan, 1968). The supernatant sol phase was stored with sodium azide at $4^{\circ} \mathrm{C}$ until tested. The sediment or gel phase was homogenized with Pancreatin (BDH Biochemicals, Poole) from pig pancreas and cultured (May, 1972b).

2. The remainder of the sample was then diluted with three times its volume of distilled water and dialysed against distilled water, with frequent changes, at $4^{\circ} \mathrm{C}$ for 72 hours. Following this the dialysate was centrifuged at $10000 \mathrm{rpm}$ at $4^{\circ} \mathrm{C}$ for 30 minutes in an MSE 18 centrifuge. The supernatant was collected and freeze dried. This material was then stored at $4^{\circ} \mathrm{C}$ until tested (Longbottom, personal communication, 1973).

Immunoglobulin estimations were performed by radial diffusion using commercially available plates (Behringwerke, AG). Low level plates were used for the estimation of sputum IgA (7S) and IgM. Precipitating antibody was detected using gel immunodiffusion techniques, as recommended by May (1972c). Freeze-dried sputum preparations were reconstituted at $60 \mathrm{mg} / \mathrm{ml}$ in normal saline; preparations prepared by highspeed centrifugation were used without modification. Reconstituted sputum could not be used for quantitative estimation of sputum immunoglobulin. Bacterial and fungal antigens used in this study were as described previously (Clarke, 1975). Antigen concentrations are listed in Table I.

\section{T A B L E I}

ANTIGEN CONCENTRATIONS USED IN IMMUNODIFFUSION STUDIES ON SPUTUM AND SERUM

\begin{tabular}{|c|c|c|c|}
\hline Antigen & Abbreviation & $\begin{array}{l}\text { Concer } \\
\text { (mg }\end{array}$ & $\begin{array}{l}\text { tration } \\
\text { (ml) }\end{array}$ \\
\hline $\begin{array}{l}H . \text { influenzae cytoplasmic } \\
H \text {. influenzae specific } \\
\text { cytoplasmic } \\
H \text {. influenzae cell wall } \\
P \text { s. aeruginosa cytoplasmic } \\
P s \text {. aeruginosa cell wall } \\
K \text {. pneumoniae cytoplasmic } \\
\text { Staph. aureus } \\
\text { Strep. pneumoniae } \\
\text { A. fumigatus }\end{array}$ & $\begin{array}{l}H(1 \cdot 5) \\
H(1 \cdot 2) \\
H C W \\
P(1 \cdot 5) \\
P C W \\
K(1 \cdot 5) \\
\varnothing \\
\text { Pn. } \\
\text { A. fum. }\end{array}$ & $\begin{array}{r}20 \\
10 \\
10 \\
10 \\
1 \\
10 \\
10 \\
2 \\
30\end{array}$ & $\begin{array}{r}10 \\
1\end{array}$ \\
\hline
\end{tabular}

The chi square test (Colton, 1974) was used to analyse the relationship between the presence of precipitating antibody and sputum purulence. The Mann-Whitney U statistic (Meredith, 1967) was used to compare sputum and serum immunoglobulin levels in the various disease groups while the coefficient of correlation (Colton, 1974) was calculated for the relationship of serum to sputum immunoglobulins. These levels were first ranked in descending order of magnitude, and the coefficient was calculated from these. Means were calculated for immunoglobulin levels in the different disease groups. However, in some groups, values were truncated and in these the medians were calculated.

\section{RESULTS}

The overall results of the precipitating antibody studies are summarized in Table II, which lists the number of times a particular organism was isolated from the sputum, the number of patients with precipitating antibody in the sputum against the antigens used (which represents the total for both methods), and the number of patients with precipitating antibody in the serum against these same antigens. In Table III the number of patients with precipitating antibody against the different antigens is compared according to the method used. It can be seen that a combination of methods is required to give a greater detection rate.

It can also be seen from Table II that there is a discrepancy between the number of patients with precipitating antibody in the serum to a particular antigen and the number of patients with precipi- 
T A B L E I I

FOR EACH DISEASE STATE, THE NUMBER OF ISOLATIONS OF A PARTICULAR ORGANISM FROM THE SPUTUM, THE INCIDENCE OF PRECIPITATING ANTIBODY DETECTED IN THE SPUTUM (COMBINATION OF METHODS) AND THE SERUM AGAINST ANTIGENS DERIVED FROM THAT ORGANISM ARE SUMMARIZED

\begin{tabular}{|c|c|c|c|c|c|c|c|c|c|c|c|c|}
\hline \multirow[b]{2}{*}{$\begin{array}{l}\text { Organism with } \\
\text { respective antigens } \\
\text { derived from it }\end{array}$} & \multicolumn{3}{|c|}{ Chronic Bronchitis (11) } & \multicolumn{3}{|c|}{ Cystic Fibrosis (9) } & \multicolumn{3}{|c|}{ Bronchiectasis (9) } & \multicolumn{3}{|c|}{ Asthma (4) } \\
\hline & $\begin{array}{l}\text { Sputum } \\
\text { Culture }\end{array}$ & $\begin{array}{l}\text { Sputum } \\
\text { Precipi- } \\
\text { tins }\end{array}$ & $\begin{array}{c}\text { Serum } \\
\text { Precipi- } \\
\text { tins }\end{array}$ & $\begin{array}{l}\text { Sputum } \\
\text { Culture }\end{array}$ & $\begin{array}{c}\text { Sputum } \\
\text { Precipi- } \\
\text { tins }\end{array}$ & $\begin{array}{c}\text { Serum } \\
\text { Precipi- } \\
\text { tins }\end{array}$ & $\begin{array}{l}\text { Sputum } \\
\text { Culture }\end{array}$ & $\begin{array}{c}\text { Sputum } \\
\text { Precipi- } \\
\text { tins }\end{array}$ & $\begin{array}{c}\text { Serum } \\
\text { Precipi- } \\
\text { tins }\end{array}$ & $\begin{array}{l}\text { Sputum } \\
\text { Culture }\end{array}$ & $\begin{array}{c}\text { Sputum } \\
\text { Precipi- } \\
\text { tins }\end{array}$ & $\begin{array}{l}\text { Serum } \\
\text { Precipi } \\
\text { tins }\end{array}$ \\
\hline $\begin{array}{l}\text { H. influenzae } \\
\text { Isolation } \\
\text { H }(1 \cdot 2) \\
\text { HCW } \\
\text { Ps. aeruginosa } \\
\text { Isolation } \\
\text { P }(1 \cdot 5) \\
\text { PCW } \\
\text { K. pneumoniae } \\
\text { Isolation } \\
\text { K }(1 \cdot 5) \\
\text { Staph. aureus } \\
\text { Isolation } \\
\text { Antigen } \\
\text { Strep. pneumoniae } \\
\text { Isolation } \\
\text { Antigen } \\
\text { A. fumigatus } \\
\text { Isolation } \\
\text { Antigen }\end{array}$ & 0 & $\begin{array}{l}1 \\
3\end{array}$ & $\begin{array}{r}11 \\
5\end{array}$ & $\begin{array}{l}0 \\
0 \\
0 \\
0\end{array}$ & $\begin{array}{l}4 \\
0 \\
2 \\
7 \\
1\end{array}$ & $\begin{array}{l}6 \\
8\end{array}$ & $\begin{array}{l}0 \\
0 \\
1 \\
0\end{array}$ & $\begin{array}{l}6 \\
0 \\
0 \\
2 \\
0\end{array}$ & $\begin{array}{l}2 \\
3 \\
1\end{array}$ & $\begin{array}{l}0 \\
0 \\
0 \\
0\end{array}$ & $\begin{array}{l}1 \\
0 \\
\\
0 \\
0 \\
0 \\
0 \\
0\end{array}$ & $\begin{array}{l}1 \\
0 \\
0 \\
1 \\
1 \\
0 \\
0 \\
0\end{array}$ \\
\hline
\end{tabular}

T A B L E I I I

NUMBER OF PATIENTS WITH PRECIPITATING ANTIBODY TO MICROBIAL ORGANISMS ACCORDING TO METHOD USED

\begin{tabular}{l|c|c|c}
\hline \multicolumn{1}{c|}{$\begin{array}{c}\text { Disease State } \\
\text { and Patient } \\
\text { Number }\end{array}$} & $\begin{array}{c}\text { Dialysis } \\
\text { Method }\end{array}$ & $\begin{array}{c}\text { High-speed } \\
\text { Centrifugation } \\
\text { Method }\end{array}$ & $\begin{array}{c}\text { Combination } \\
\text { of } \\
\text { Methods }\end{array}$ \\
\hline $\begin{array}{l}\text { Chronic } \\
\text { bronchitis (11) }\end{array}$ & 5 & 5 & 7 \\
$\begin{array}{l}\text { Cystic fibrosis (9) } \\
\text { Bronchiectasis (9) }\end{array}$ & 6 & 9 & 9 \\
Asthma (4) & 5 & 5 & 7 \\
\hline
\end{tabular}

tating antibody detected against the same antigen in the sputum. This discrepancy is also noted between sputum and serum antibody. This latter situation is summarized in Table IV.

Table V summarizes immunoglobulin estimations made on sputum and matching serum samples in the disease groups. It is appreciated that, by estimating $7 \mathrm{~S} \operatorname{IgA}$ only, the total amount of $\operatorname{IgA}$ present in the sputum is underestimated.

T A B L E I V

PRECIPITATING ANTIBODY AGAINST BACTERIAL ANTIGENS IN THE SPUTUM AND SERUM FOR THOSE PATIENTS IN WHOM THE SPUTUM RESULT DIFFERED FROM THAT IN THE SERUM

\begin{tabular}{|c|c|c|c|c|c|}
\hline \multicolumn{2}{|c|}{ Sputum Result } & \multicolumn{4}{|c|}{ Serum Result } \\
\hline $\begin{array}{l}\text { PCW } \\
\text { PCW }\end{array}$ & $\mathrm{HCW}$ & $\begin{array}{l}\mathrm{HCW} \\
\mathrm{HCW}(1 \cdot 2)\end{array}$ & $\begin{array}{l}\mathrm{H}(1 \cdot 2) \\
\mathrm{K}(1 \cdot 5)\end{array}$ & $\begin{array}{l}\mathrm{P}(1 \cdot 5) \\
\mathrm{Pn}\end{array}$ & \\
\hline $\begin{array}{l}\mathrm{H}(1 \cdot 2) \\
\mathrm{PCW} \\
\mathrm{PCW} \\
\mathrm{H}(1 \cdot 2)\end{array}$ & $\mathrm{H}(1 \cdot 2)$ & $\begin{array}{l}\mathrm{K}(1 \cdot 5) \\
\mathrm{HCW} \\
\mathrm{H}(1 \cdot 2) \\
\mathrm{HCW}\end{array}$ & $\begin{array}{l}\mathrm{H}(1 \cdot 2) \\
\varnothing\end{array}$ & $K(1 \cdot 5)$ & $\varnothing$ \\
\hline
\end{tabular}

Comparison of the various sputum and seruni immunoglobulin values was carried out between the various disease states. A number of differences were found to be statistically significant $(P<0.05)$ o Sputum IgA (7S) in patients with chronic brone chitis was significantly lower than that found in patients with cystic fibrosis and bronchiectasiso Serum IgG in patients which chronic bronchitis was significantly lower than the IgG level found in patients with cystic fibrosis and bronchiectasis. The serum IgG was significantly lower in patient $\vec{E}$ with bronchiectasis than in patients with cystio fibrosis. Serum IgM levels in patients with chronie bronchitis were significantly lower than in patients with cystic fibrosis.

An analysis was made of sputum and serump immunoglobulins in patients with chronic brone chitis and bronchiectasis having 25\% (MP+) and $75 \%(\mathrm{MP}+++)$ or more pus in the sputum. The only significant relationship found was that the serum IgG was higher in patients with $25 \%$ pu९ in their sputum compared to those with $75 \%$ of more pus in patients with chronic bronchitis. The्E number of patients (14) with MP+ sputum whe had precipitating antibody in the sputum (8) wa compared to those patients (19) with $\mathrm{MP}+++\frac{\mathrm{C}}{\mathrm{D}}$ sputum and precipitating antibody in the sputunf? (16). No significant difference was found. Theo coefficients of correlation were calculated to se. if serum immunoglobulin could be correlated t\$ the level of sputum immunoglobulins. No signifi $\vec{\Phi}$ cant correlation was found. 
T A B L E V

SPUTUM AND SERUM IMMUNOGLOBULIN LEVELS EXPRESSED AS GRAMS/LITRE

\begin{tabular}{|c|c|c|c|c|c|c|}
\hline \multirow{2}{*}{$\begin{array}{c}\text { Disease and } \\
\text { Patient Number }\end{array}$} & \multicolumn{2}{|c|}{ IgG } & \multicolumn{2}{|c|}{$\operatorname{IgA}(7 S)$} & \multicolumn{2}{|c|}{ IgM } \\
\hline & Sputum & Serum & Sputum & Serum & Sputum & Serum \\
\hline $\begin{array}{l}\text { Chronic bronchitis (11) } \\
\text { Range } \\
\text { Mean } \\
\text { SD } \\
\text { Cystic Fibrosis (9) } \\
\text { Range } \\
\text { Mean } \\
\text { SD } \\
\text { Bronchiectasis (9) } \\
\text { Range } \\
\text { Mean } \\
\text { SD } \\
\text { Asthma (4) } \\
\text { Range } \\
\text { Mean } \\
\text { SD }\end{array}$ & $\begin{array}{c}<0 \cdot 7-6 \cdot 3 \\
3 \cdot 35^{*} \\
\\
<0 \cdot 7-9 \cdot 3 \\
5 \cdot 8^{*} \\
\\
2 \cdot 3-7 \cdot 3 \\
5 \cdot 38 \\
1 \cdot 94 \\
<0 \cdot 7-7 \cdot 2 \\
3 \cdot 4^{*}\end{array}$ & $\begin{array}{c}5 \cdot 9-15 \cdot 01 \\
11 \cdot 35 \\
3 \cdot 52 \\
14 \cdot 13-31 \cdot 8 \\
19 \cdot 87^{*} \\
\\
10 \cdot 83->20 \\
14 \cdot 55^{*} \\
\\
6 \cdot 55-12 \cdot 05 \\
8 \cdot 59 \\
2 \cdot 4\end{array}$ & $\begin{array}{c}<0 \cdot 1-0.94 \\
0.68 * \\
\\
0.48-1 \cdot 1 \\
0 \cdot 86 \\
0 \cdot 203 \\
\\
0 \cdot 5-1 \cdot 1 \\
0 \cdot 85 \\
0.2 \\
0.74-0.94 \\
0.85 \\
0.096\end{array}$ & $\begin{array}{c}1 \cdot 26->4 \cdot 5 \\
3 \cdot 07^{*} \\
1 \cdot 45-7 \\
3 \cdot 24^{*} \\
\\
1 \cdot 64->4 \cdot 5 \\
2 \cdot 74^{*} \\
\\
1 \cdot 84-2 \cdot 12 \\
2 \cdot 03 \\
0 \cdot 13\end{array}$ & $\begin{array}{c}0-0.45 \\
0.12 \\
0.203 \\
0-0.54 \\
0.19 \\
0.23 \\
0-0.6 \\
0.21 \\
0.25 \\
0 \\
0\end{array}$ & $\begin{array}{c}0 \cdot 83-1 \cdot 71 \\
1 \cdot 17 \\
0 \cdot 308 \\
1 \cdot 56-8 \cdot 38 \\
2 \cdot 15^{*} \\
\\
0 \cdot 66-3 \cdot 26 \\
1 \cdot 84 \\
0 \cdot 82 \\
1 \cdot 08-1 \cdot 86 \\
1 \cdot 55 \\
0.34\end{array}$ \\
\hline
\end{tabular}

SD = standard deviation; $*$ = median. Mean unable to be calculated because of truncated values

Normal serum values from this laboratory (g/litre): IgG 5-15; IgA 1.25-4.5; IgM 0.5-1.7.

\section{DISCUSSION}

A problem with any study on sputum is to decide what contribution is made to the results by serum transudation, and formulae have been derived to estimate this (Deuschl and Johansson, 1974). Results presented in this study suggest that serum transudation may not be such an important factor as far as immunoglobulins are concerned. This is supported by the observations that precipitins present in serum are not detected in the sputum in many instances, precipitating antibody may be detected in the sputum but not in the serum, the degree of bronchial inflammation as judged by sputum purulence does not appear to have any relationship to sputum immunoglobulin levels or the presence of precipitating antibody, IgM is rarely present in the sputum, and the level of immunoglobulin in the serum bears no relationship to the level of immunoglobulin present in the sputum.

This study confirms the finding in a previous study that precipitating antibody may be detected against bacterial and fungal antigens in the sputum (Clarke, 1975). Detection of precipitating antibody against bacterial antigens in the serum of patients with these diseases has led some investigators to attach pathogenic significance to certain organisms that may be isolated from the sputum in these diseases (May, 1975). It is often difficult in an individual patient to assess the pathogenic significance of an organism isolated from a sample of sputum at a given time. A search for sputum precipitins may facilitate this assessment. Support for this idea comes from a study of precipitating antibody to other inhaled antigens, viz, chicken antigens. It was shown by bronchial challenge testing that the antigens against which sputum precipitating antibody was directed had more relevance clinically than those against which serum antibody was directed (Warren and Tse, 1974). A study of cystic fibrosis patients also demonstrated higher titres of sputum than of serum precipitins to certain antigens (Wallwork et al., 1974).

The detection of precipitating antibody to bacterial antigen in sputum raises the possibility that type III or Arthus reactions could play a part in these conditions, as has been demonstrated for Aspergillus fumigatus (Katz and Kniker, 1973). In support of this was the demonstration of extensive deposits of immunoglobulins and complement immune complexes in the respiratory tract of patients with cystic fibrosis (McFarlane et al., 1975).

It is apparent from this study that the antigens used in the detection of precipitating antibody are of importance. Certainly with Pseudomonas aeruginosa and, to a lesser extent, Haemophilus influenzae it is the cell wall antigen that appears to have more relevance. This may be one reason why precipitating antibody was not detected against $P$ s. aeruginosa in a study of the sputum of patients with cystic fibrosis (Wallwork et al., 1974).

As the method of preparation of the cell wall antigen is the same as that for the preparation of endotoxin and the cell wall and cytoplasmic antigens of $H$. influenzae have been shown to contain endotoxin (Branefors-Helander, 1973; Van Der Zwan, Orie, and De Vries, 1975) the detection of precipitating antibody to these antigens 
suggests that endotoxin is being released into the bronchial tree. This may contribute to the pathological processes by activation of the alternate pathway for complement (Götze and MüllerEberhard, 1971), recruitment (Wittels et al., 1974) and pulmonary intravascular sequestration of leucocytes (Kilburn et al., 1974), increasing vascular permeability, allowing inhaled antigens access to the circulation (Parish, 1972), releasing and causing de novo synthesis of histamine directly (Szetivanyi, 1971) with subsequent mucous hypersecretion and mucosal oedema (Brocklehurst, 1970), and increased bronchial reactivity in a similar manner to that produced by the endotoxin of Bordetella pertussis in experimental animals (Reed, 1968).

The immunoglobulin results are of interest. The low IgA (7S) in the sputum of patients with chronic bronchitis compared to the other disease states raises the possibility that its production in chronic bronchitis may be abnormal, as suggested elsewhere (Medici and Buergi, 1971). The lack of IgM in the sputum is supported by other studies (Falk et al., 1972; Gump et al., 1973) while the presence of IgG and IgA (7S) in the sputum of patients with bronchiectasis and cystic fibrosis gives further support to the concept that a defect of local immunoglobulin production is probably not the cause of the chronic infection seen in these conditions (Martinez-Tello, Braun, and Blane, 1968). The significant differences in the sputum and serum immunoglobulins in the different disease states reported here may reflect a difference in the severity of the infection or a difference in the capacity to react to infection.

I should like to thank Dr. I. Daz and Miss G. Leballeur, of the Department of Experimental Pathology, Cardiothoracic Institute, for arranging highspeed centrifugation; Mr. S. Nagarajah, of Brompton Hospital, for carrying out immunoglobulin estimations; Mr. D. E. Roberts, Chief Technician in the Department, for technical help; and the Board of Governors, National Heart and Chest Hospitals, Brompton Hospital for financial support.

\section{REFERENCES}

Austrian, R. (1968). The bacterial flora of the respiratory tract. Some knowns and unknowns. Yale Journal of Biology and Medicine, 40, 400.

Biberfeld, G. and Sterner, G. (1971). Antibodies in bronchial secretions following natural infections with Mycoplasma pneumoniae. Acta Pathologica et Microbiologica Scandinavica Section B, 79, 599.

Branefors-Helander, P. (1973). Serological studies of Haemophilus influenzae. III. The endotoxic effect of various antigen preparations and the relation between this effect and demonstrable precipitinogens. International Archives of Allergy and $\overline{\overline{\bar{S}}}$
Applied Immunology, 44, 585.

Brocklehurst, W. E. (1970). Pharmacological factors mediating bronchial obstruction. In Bronchitisu III (Proceedings of the Third International Sym-s posium on Bronchitis at Groningen, The Nether $\overrightarrow{0}$ lands, September 1969), edited by N. G. M. Orieand R. van Der Lende, p. 279, Royal Vangorcum $\vec{\omega}$ Assen.

Brogan, T. D., Ryley, H. C., Neale, L., and Yassa, J (1975). Soluble proteins of bronchopulmonaryw secretions from patients with cystic fibrosis, asthma, and bronchitis. Thorax, 30, 72.

Brumfitt, W., Willoughby, M. L. N., and Bromley L. L. (1957). An evalution of sputum examina-0 tion in chronic bronchitis. Lancet, 2, 1306.

Clarke, C. W. (1975). Precipitating antibody in the sputum in chronic respiratory disease. Post graduate Medical Journal, 51, 147.

Colton, T. (1974). Statistics in Medicine, p. 174. Little Brown, Boston.

Deuschl, H. and Johansson, S. G. O. (1974). Immunoglobulins in tracheo-bronchial secretion withe special reference to IgE. Clinical and Experimental Immunology, 16, 401.

Falk, G. A., Okinaka, A. J., and Siskind, G. W응 (1972). Immunoglobulins in the bronchial wash ings of patients with chronic obstructive pulo monary disease. American Review of Respirator Diseases, 105, 14.

Götze. O. and Müller-Eberhard, H. J. (1971). The C3-activator system: an alternate pathway of complement activation. Journal of Experimenta Medicine, 134, $90 \mathrm{~S}$.

Gump, D. W., Christmas, W. A., Forsyth, B. R. Phillips, C. A., and Stouch, W. H. (1973). Serum and secretory antibodies in patients with chronie bronchitis. Archives of Internal Medicine, 132 次 847.

Katz, R. M. and Kniker, W. T. (1973). Infantile hypersensitivity pneumonitis as a reaction ti் organic antigens. New England Journal of Medis cine, 288, 233.

Kilburn, K. H.. Hudson, A. R., Halprin, G. M.ㅇํ McKenzie, W. N., and Merchant, J. A. (1974) D Two patterns for bronchial damage from in haled materials. Chest, 65, 4, Supplement 61S.

Lees, A. W. and McNaught, W. (1959). Bacteriologf of lower respiratory tract secretions, sputum, and upper-respiratory-tract secretions in 'normals and chronic bronchitics. Lancet, 2, 1112.

Longbottom, J. L. (1973). Personal communication McFarlane, H., Holzel, A., Brenchley, P., Allarø오 J. D. Wallwork J. C., Singer, B. E., and WorsleyФ B. (1975). Immune complexes in cystic fibrosis British Medical Journal, 1, 423.

Martinez-Tello, F. J., Braun, D. G., and Blanc, W. A (1968). Immunoglobulin production in bronchia mucosa and bronchial lymph nodes, particularle in cystic fibrosis of the pancreas. Journal og Immunology, 101, 989. 
May, J. R. (1972). The Chemotherapy of Chronic Bronchitis and Allied Disorders, 2nd edition, (a) p. 4, (b) p. 95, (c) p. 99. The English Universities Press Ltd., London.

May, J. R. (1975). The flora of the respiratory tract in chronic disease. Postgraduate Medical Journal, 51, 144.

Medici, T. C. and Buergi, H. (1971). The role of immunoglobulin $A$ in endogenous bronchial defense mechanisms in chronic bronchitis. American Review of Respiratory Diseases, 103, 784.

Meredith, W. M. (1967). Basic Mathematical and Statistical Tables for Psychology and Education, p. 288. McGraw-Hill, New York.

Parish, W. E. (1972). Host damage resulting from hypersensitivity to bacteria. Symposia of the Society for General Microbiology, 22, 157.

Reed, C. E. (1968). Pertussis sensitization as an animal model for the abnormal bronchial sensitivity of asthma. Yale Journal of Biology and Medicine, 40, 507.

Ryley, H. C. and Brogan, T. D. (1968). Variation in the composition of sputum in chronic chest diseases. British Journal of Experimental Pathology, 49, 625.

Ryley, H. C. and Brogan, T. D. (1973). Quantitative immunoelectrophoretic analysis of the plasma proteins in the sol phase of sputum from patients with chronic bronchitis. Journal of Clinical Pathology, 26, 852 .

Shore, S. L., Potter, C. W., and Stuart-Harris, C. H. (1973). Antibody response to inactivated influenza vaccine given by different routes in patients with chronic bronchopulmonary disease. Thorax, 28 , 721.
Smith, H. (1972). The little-known determinants of microbial pathogenicity. Symposia of the Society for General Microbiology, 22, 1.

Szetivanyi, I. (1971). Effect of bacterial products and adrenergic blocking agents on allergic reactions. In Immunological Diseases, 2nd edition, edited by M. Samter, Vol. 1, p. 356. Little, Brown, Boston.

Tager, I. and Speizer, F. E. (1975). Role of infection in chronic bronchitis. New England Journal of Medicine, 292, 563.

Van Der Zwan, J. C., Orie, N. G. M., and De Vries, K. (1975). Biphasic reaction after inhalation of Haemophilus influenzae in patients with chronic nonspecific lung disease. Clinical Allergy, 5, 225.

Wallwork, J. C., Brenchley, P., McCarthy, J., Allan, J. D., Moss, D., Milford Ward, A., Holzel, A., Williams, R. F., and McFarlane, H. (1974). Some aspects of immunity in patients with cystic fibrosis Clinical and Experimental Immunology, 18, 303.

Warren, C. P. W. and Tse, K. S. (1974). E: itrinsic allergic alveolitis owing to hypersensitivity to chickens-significance of sputum precipitins. American Review of Respiratory Diseases, 109, 672.

Wittels, E. H., Coalson, J. J., Welch, M. H., and Guenter, C. A. (1974). Pulmonary intravascular leucocyte sequestration: a potential mechanism of lung injury. American Review of Respiratory Diseases, 109, 502.

Requests for reprints tc: Dr. C. W. Clarke, Royal Brisbane Hospital, Brisbane, Queensland 4029, Australia. 